\title{
Trade-off Study of Systems Supporting the Capsule Closure Welding Processes
}

\author{
Larry Zirker
}

April 2012

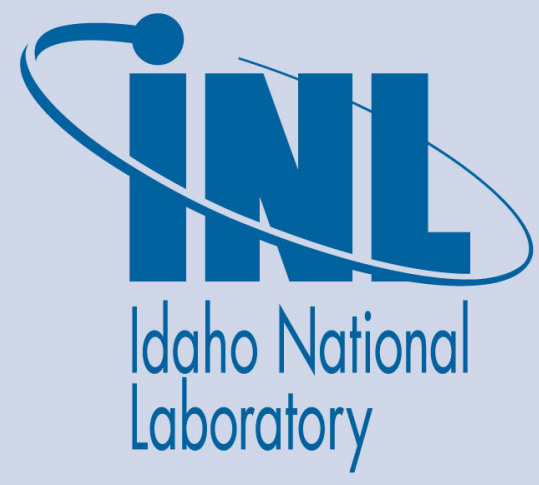

The INL is a U.S. Department of Energy National Laboratory operated by Battelle Energy Alliance 


\section{DISCLAIMER}

This information was prepared as an account of work sponsored by an agency of the U.S. Government. Neither the U.S. Government nor any agency thereof, nor any of their employees, makes any warranty, expressed or implied, or assumes any legal liability or responsibility for the accuracy, completeness, or usefulness, of any information, apparatus, product, or process disclosed, or represents that its use would not infringe privately owned rights. References herein to any specific commercial product, process, or service by trade name, trade mark, manufacturer, or otherwise, does not necessarily constitute or imply its endorsement, recommendation, or favoring by the U.S. Government or any agency thereof. The views and opinions of authors expressed herein do not necessarily state or reflect those of the U.S. Government or any agency thereof. 


\title{
Trade-off Study of Systems Supporting the Capsule Closure Welding Processes
}

\author{
Larry Zirker
}

April 2012

Idaho National Laboratory Idaho Falls, Idaho 83415

http://www.inl.gov

Prepared for the U.S. Department of Energy Office of Nuclear Energy Under DOE Idaho Operations Office

Contract DE-AC07-05ID14517 




\section{CONTENTS}

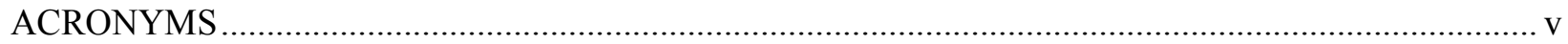

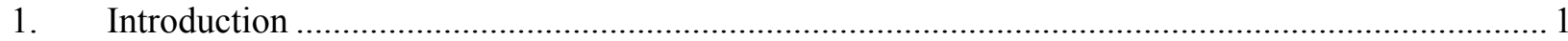

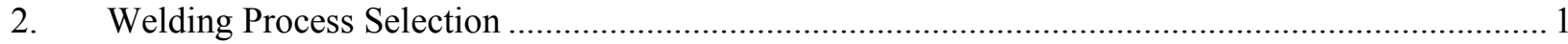

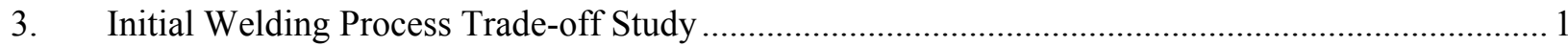

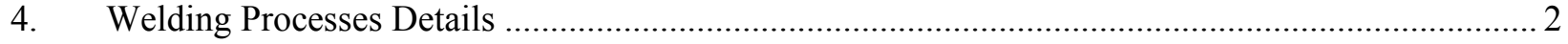

4.1 Gas Tungsten Arc Welding (Score 130) ............................................................................. 2

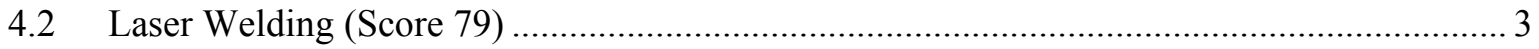

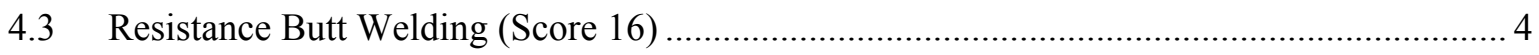

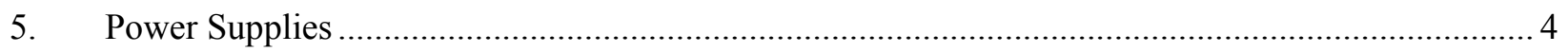

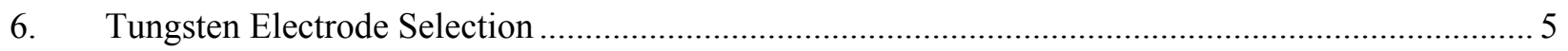

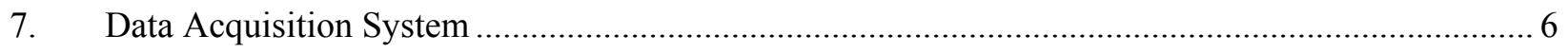

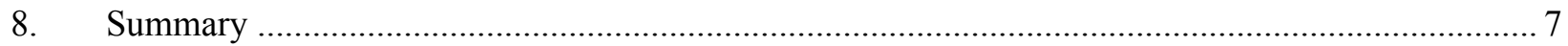

\section{FIGURES}

Figure 1. Progression from fuel element pieces to finished weld .......................................................... 3

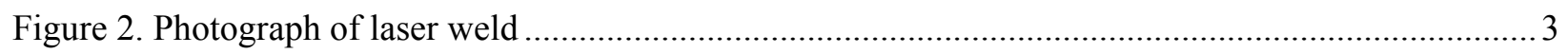

Figure 3. Sectioned laser weld showing cracks and porosity ............................................................. 3

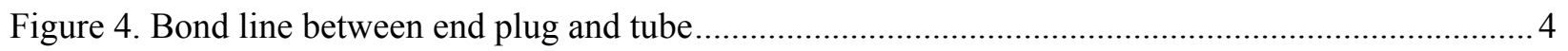

Figure 5. 5,000X SEM view of end plug to tube bond line ............................................................. 4

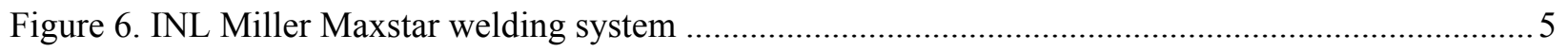

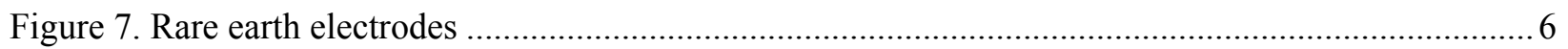

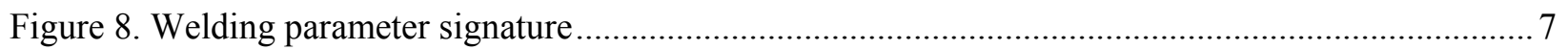

\section{TABLES}

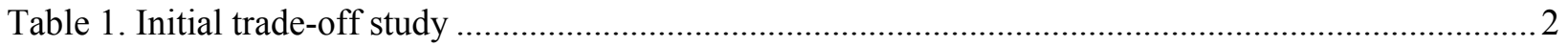




\section{ACRONYMS}

ATR Advanced Test Reactor

COTS commercial off-the-shelf

EBR Experimental Breeder Reactor

GTAW Gas Tungsten Arc Welding

INERI International Nuclear Energy Research Initiative

INL Idaho National Laboratory

LWR light water reactor

ODS oxide dispersion strengthened

RBW Resistance Butt Welding

ROK Democratic People's Republic of Korea 


\section{Trade-off Study of Systems Supporting the Capsule Closure Welding Processes}

\section{Introduction}

The overall thrust of the United States-Democratic People's Republic of Korea (ROK) International Nuclear Energy Research Initiative (INERI) and Joint Fuel Cycle Studies Project is to reprocess spent Korean fuel from spent light water reactor (LWR) elements, cast the reprocessed fuel into fuel pins, encapsulate the fuel into cladding, and then irradiate the fuel in the Advanced Test Reactor (ATR). This study captures the due diligence conducted to ascertain the best hardware or systems for supporting the capsule closure welding process. The quality and precision of welded fuel elements is paramount in the nuclear environment. One of the main welding deliverable for this project is a defined welding process capable of generating consistent and reliable closure welds.

Other considerations include:

- Minimal design risk and developmental time. All equipment and systems should be commercial off-the-shelf (COTS) to the extent possible, and should leverage other designs and existing systems

- $\quad$ System designed for hot cell operations. All designs should be based on operability in a hot cell environment using master slave arms and manipulators.

- Capability to producing twelve pins per day. The capsule welding system should be capable of welding twelve closure welds a day. The system needs to be robust, but not centered around a high throughput of pins.

The major systems of the capsule closure welding process include:

- Welding processes (see Section 4)

- Power supplies (see Section 5)

- Tungsten electrodes (see Section 6)

- Data acquisition systems (see Section 7).

\section{Welding Process Selection}

Several welding processes are used to join fuel elements; however, fewer are applicable for in-cell usage. Three welding processes are proposed for consideration for the in-cell welding process to perform the closure welding of the rodlet and capsules. They are:

- Gas Tungsten Arc Welding

- Laser Welding

- Resistance Welding.

\section{Initial Welding Process Trade-off Study}

An initial trade-off study (see Table 1) shows values defining the welding processes. The best system is indicated by the highest score; more details are included in the subsequent paragraphs. 
Table 1. Initial trade-off study

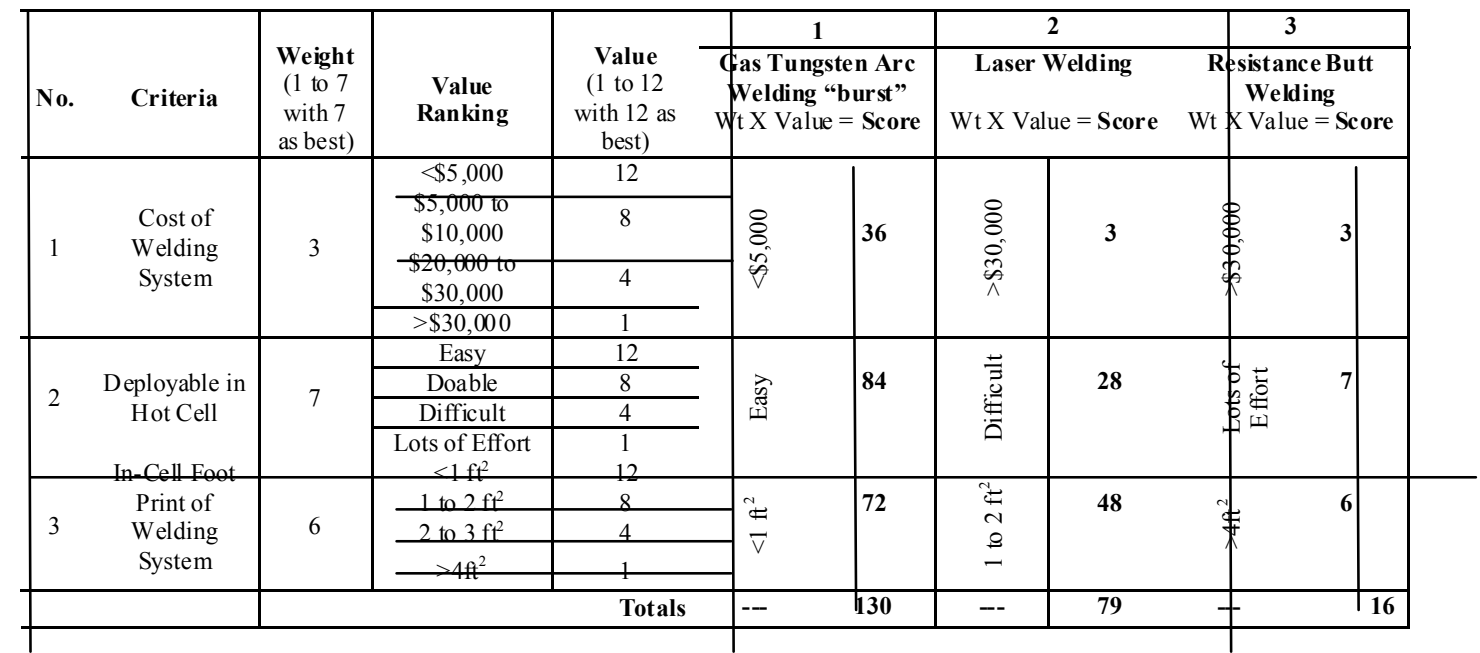

Criteria:

Cost of Welding System is defined as the cost purchase a total functioning welding system to perform the closure welds.

Deployable in Hot Cell is defined as the time needed to replace the equipment, item or personnel.

Foot Print of Welding System is defined as an estimate on in increase of productivity if the HFEF hot cell piece of equipment, item or personnel were replaced or added.

Weight is the multiplier value that is arbitrarily defined by the project team to represent a weight factor of importance to the criteria. The weight values are between 1 to 7 with 7 being the best.

Value Ranking is a decompositional breakdown that provides a range of values or basis for ranking the Limitation with the Criteria. Score is the product of the Weight and the Value of each Criterion.

Total is the sum of all scores for each Limitation. The highest score wins as most important.

\section{Welding Processes Details \\ 4.1 Gas Tungsten Arc Welding (Score 130)}

The Gas Tungsten Arc Welding (GTAW) process has been used for years in the nuclear industry. This type of welding for sealing fuel elements is often referred to as "burst" welding. It is essentially a single spot weld done vertically and in line with the end of a fuel element with the purpose of sealing it closed or encapsulating the fuel inside of a tube. This type of fuel element closure welding was used for years on the Experimental Breeder Reactor (EBR)-II, located at the Idaho National Laboratory (INL). A bank of charged capacitors was used as the power supply, and when the fuel element was placed under the electrode, the capacitors would be discharged and the arc would quickly seal the end of the elements. Thousands of these welds were done during the lifetime of EBR-II. With modern solid state electronics, the same energy discharge can be mimicked using programmable GTAW systems. This method of encapsulating end plugs on fuel elements is quite robust and is dependent mainly on the exact alignment of the tube with the tungsten electrode. Figure 1 shows the progression between fuel element pieces, end plug in a tube, and a completed weld using a GTAW system. 


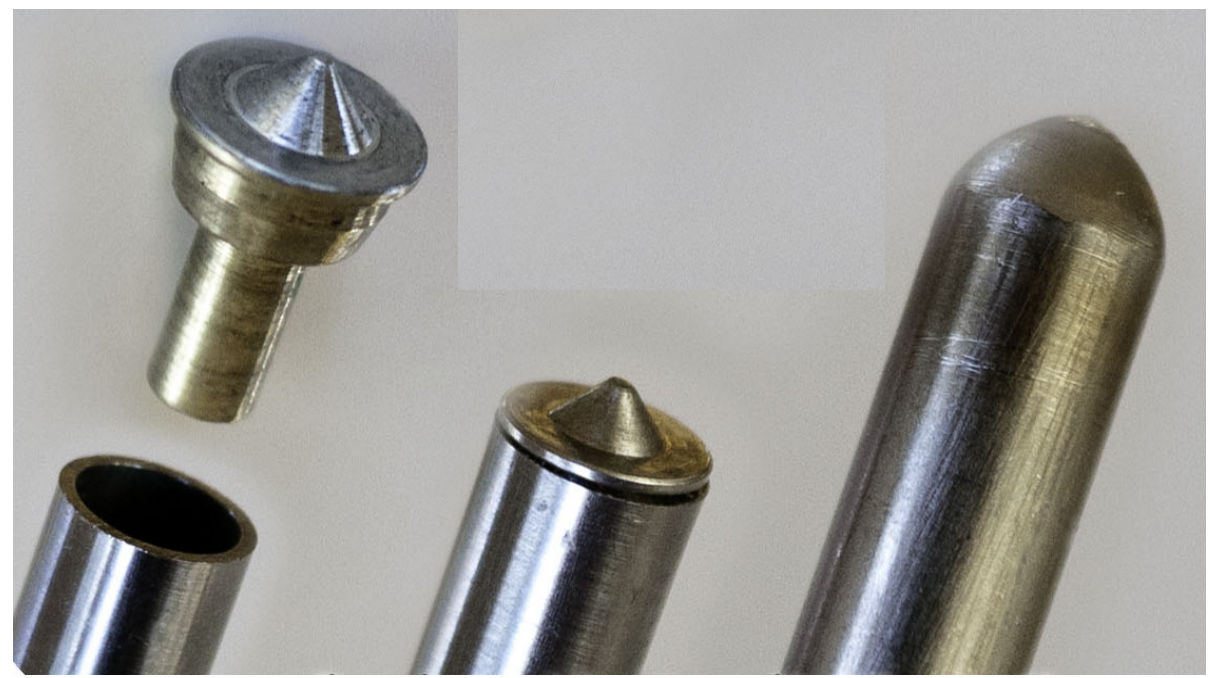

Figure 1. Progression from fuel element pieces to finished weld

Orbital GTAW tube weld is another method used successfully for making fuel elements in glove boxes, but this method requires extensive hands-on manipulation and alignment not possible in hot cell environments. The method was not considered with the GTAW process because it is not considered feasible for hot cell use.

\subsection{Laser Welding (Score 79)}

The INL has a limited history of hot cell laser welding of fuel elements, and recent preliminary laser welding tests show marginal quality. Figure 2 shows an excellent external photograph; however, Figure 3 shows root cracks and porosity inherent in the marginal weld. The testing was performed on 0.230 diameter HT9 (martensitic material) tube and end plug with a Crawford-Laserstar 1.064nm Nd:Yag system with $80 \mathrm{~J}$ max at $400 \mathrm{v} / 20 \mathrm{~ms}$. More work is scheduled with different parameters and end plug configurations to obtain crack free results.

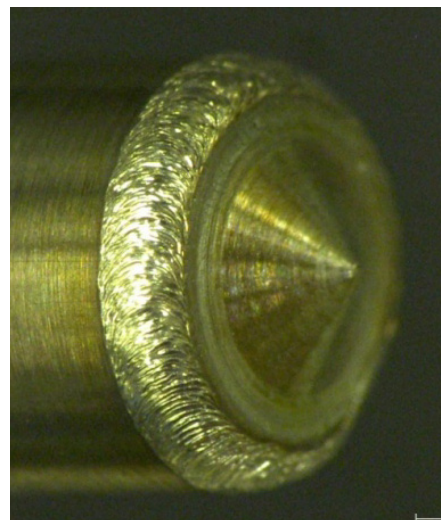

Figure 2. Photograph of laser weld

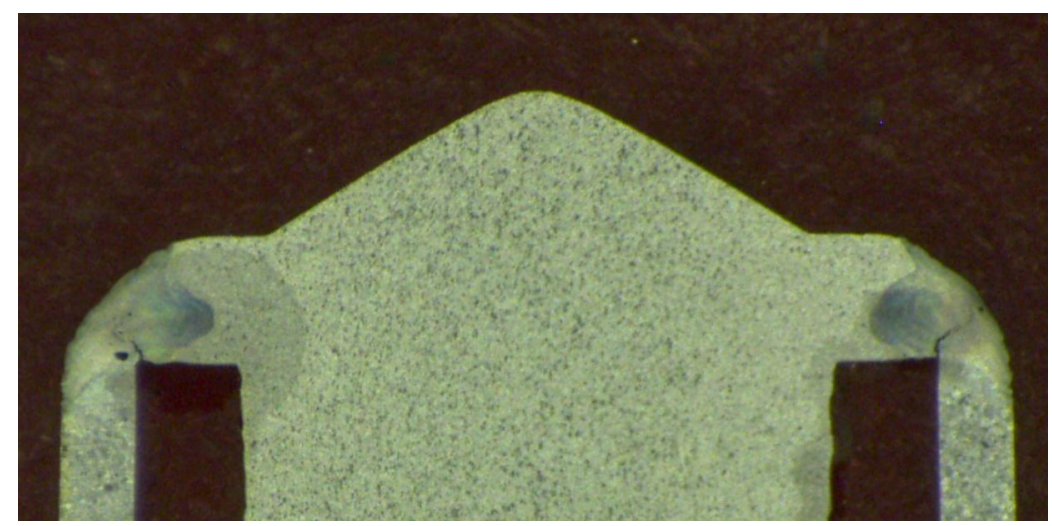

Figure 3. Sectioned laser weld showing cracks and porosity

Laser welding in a hot cell is possible. Although the welding system would not be in the hot cell, the hot cell radiation is harmful to the fiber optic cables inside the cell. A rotary lathe would also be required. Fusion welds with a small plenum have a propensity for blowing out welds. Quick welds or short welding times typically have much less blow-outs issues from the heated gases inside of the element. Tests are being conducted to assess the laser welding of a closed element and ascertain if the laser welding has a propensity to blow out welds. 


\subsection{Resistance Butt Welding (Score 16)}

Resistance Butt Welding (RBW) is a solid state, resistance welding process that joins the ends of two cylindrical elements. However, the process does not melt the interface between the end plug and tubing materials typical of fusion processes. The INL has some maturity and knowledge using RBW to join end plugs and tubes, but has no experience joining end plugs and tubes in the hot cell. Recent work joining oxide dispersion strengthened (ODS) tubing showed excellent result. Figure 4 and Figure 5 show examples of excellent bonding between a martensitic end plug and a ferritic ODS tube using a resistance welding process.

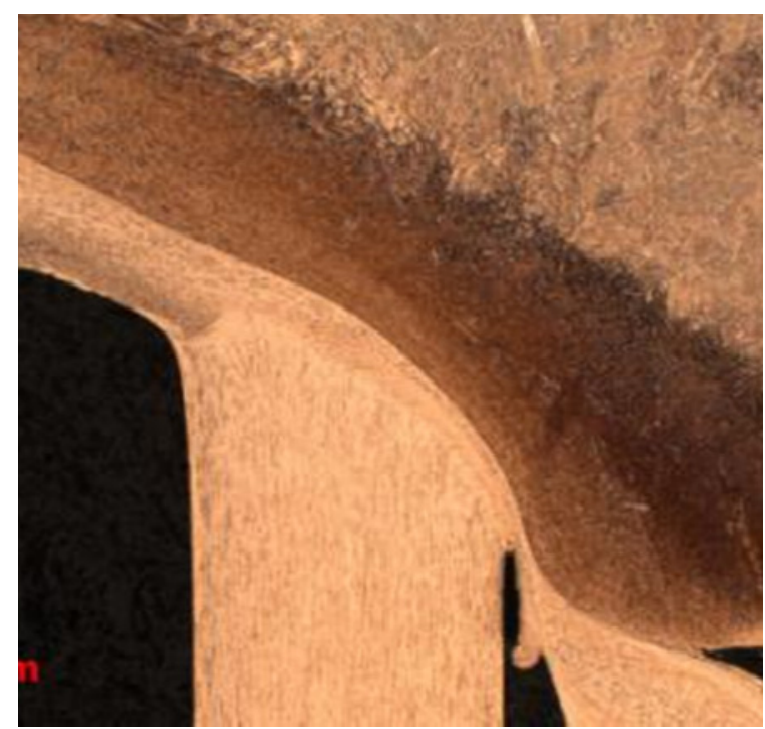

Figure 4. Bond line between end plug and tube

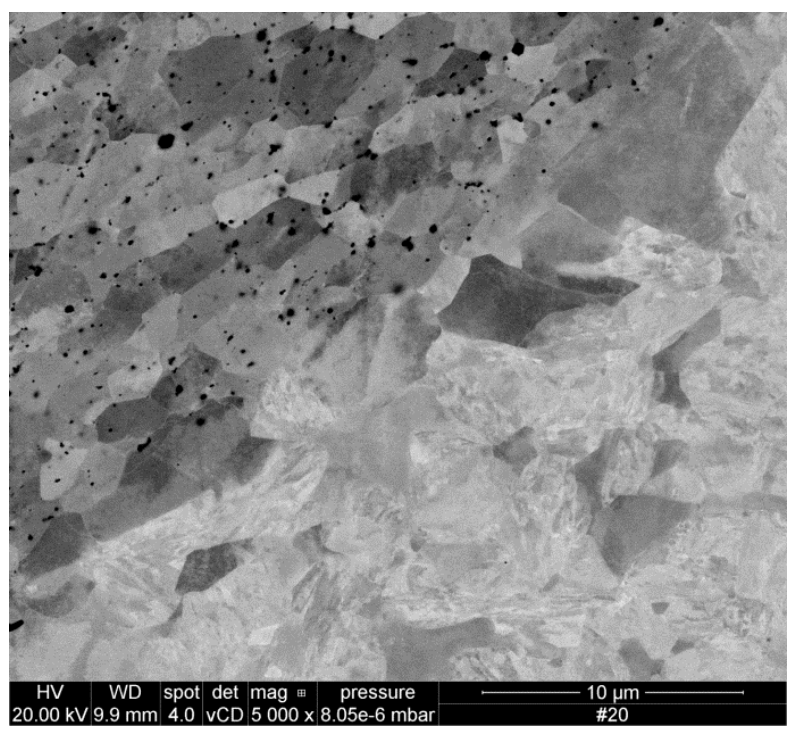

Figure 5. 5,000X SEM view of end plug to tube bond line

The INL RBW system was recently relocated into a new laboratory, and welding fixtures are being ordered to join 0.230 diameter tubing and end plugs. The footprint is large $\left(5 \mathrm{ft}^{2}\right)$ for this welding system, and a non-hydraulic oil powered ram needs to be installed for in-cell use since hydraulic oil would not be allowed in a hot cell. Tests will be conducted in the near future to demonstrate usability of RBW for incell work.

\section{Power Supplies}

The trade-off study selected GTAW as the best welding process. The project requires the welding system to possess the following criteria:

- Programmability of the welding parameters

- COTS power supply

- COTS control system

- Factory support

- 300-ampere solid state power supply

- Relatively low cost.

A variety of GTAW power supplies exist on the market, and several vendors were investigated:

- Lincoln Electric 
- Thermadyne

- AMET systems

- Miller Electric.

When all of the criteria were considered, the Miller Electric 300 Maxstar system exceeded all other power supplies. The Miller Maxstar was the only system with an integral remote programmable system allowing high peak amperage welds with a quick down-slope decay required in the welding of fuel elements. Fuel elements have a limited plenum region and are known to generate enough air pressure from the heat of welding to blow-out the closure weld. Therefore, a quick welding cycle with high welding amperage with a quick decay time is essential for encapsulating fuel elements. The other welding systems had add-on programmable modules that added $\$ 10,000$ to the package. Figure 6 shows the Miller Maxstar welding system selected and used for this encapsulation effort.

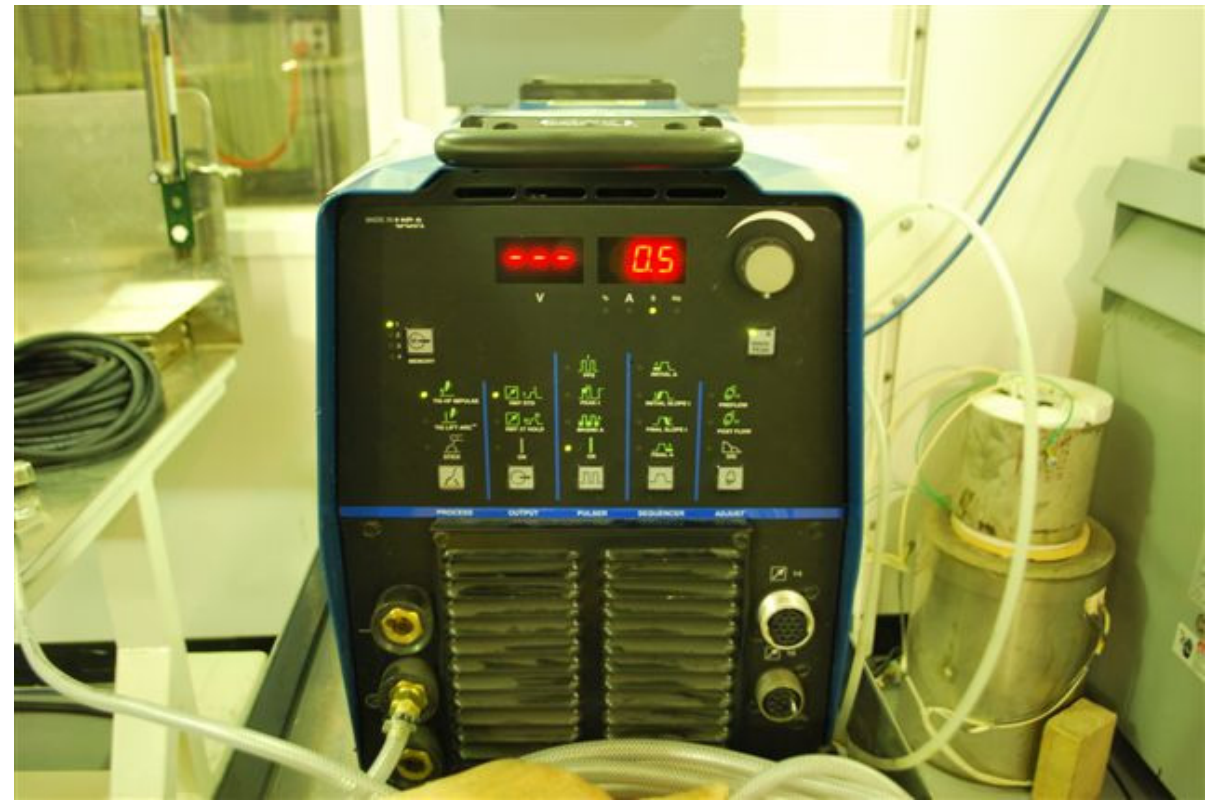

Figure 6. INL Miller Maxstar welding system

\section{Tungsten Electrode Selection}

GTAW systems use a tungsten electrode to carry the welding current and create the fusion or melting of the base metal. Not all electrodes are created equal, and since this welding occurs in a hot cell environment, the longest welding life is mandatory because of the difficulty in changing out an electrode using a manipulator. For years, the optimum electrode was the $2 \%$ thorium alloy, but since thorium is radioactive, the sharpening and polishing of the electrodes spreads contamination and creates environmental problems in machine shops and welding laboratories. Electrode life was researched, and it was discovered that a mixture of rare earth alloys possess the best electrode life. The Tri-Mix nonradioactive tungsten electrodes from Diamond Ground Products, Inc. were found to be the best arc starting and long-life electrode on the market. The combination of lanthanum, cerium, and another proprietary alloy make an excellent long-life non-radioactive electrode. Figure 7 shows the tri-mix tungsten electrode. The 3/32-inch electrodes were purchased with a mirror polished taper on both ends of the electrode. Having both ends of the electrode ground essentially doubles the effective use of the electrodes. The dimensions taper included a 20 degree angle and a 0.020-inch flat. 


\section{Tri-Mix ${ }^{\text {TM }}$ WS2 White (Non-Radioactive)}

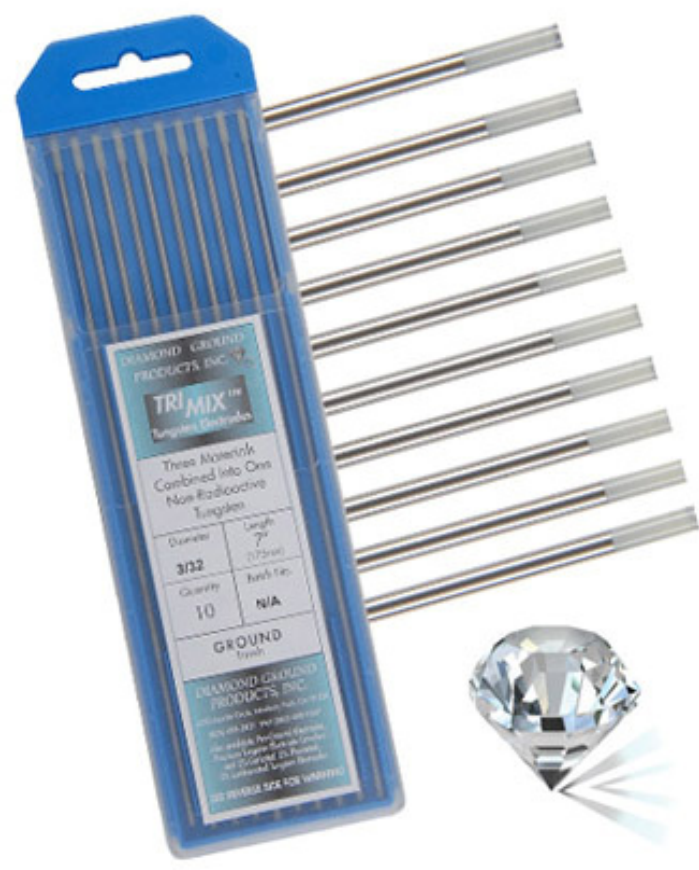

Non-radioactive tungsten with similar performance as $2 \%$ Thoriated tungsten. Three oxides scientifically balanced to promote migration and evaporation rates that result in extended tungsten life. Offers stability and consistency not seen on most other types of tungsten. Results include, increase in weld quality and dramatic increase in service.

Choose from the following sizes:

\begin{tabular}{|c|c|c|c|}
\hline \multicolumn{2}{|c|}{ Diameter } & $\begin{array}{c}\text { Wolfram } \\
\text { Part\# }\end{array}$ & $\begin{array}{c}\text { Wolfram } \\
\text { Price }\end{array}$ \\
\hline .020 & $(0.5 \mathrm{~mm})$ & TRI-020 & Call \\
\hline .040 & $(1.0 \mathrm{~mm})$ & TRI-040 & $\$ 21.57$ \\
\hline $1 / 16$ & $(1.6 \mathrm{~mm})$ & TRI-1/16 & $\$ 24.91$ \\
\hline $3 / 32$ & $(2.4 \mathrm{~mm})$ & TRI-3/32 & $\$ 49.56$ \\
\hline $1 / 8$ & $(3.2 \mathrm{~mm})$ & TRI-1/8 & $\$ 87.35$ \\
\hline $5 / 32$ & $(4.0 \mathrm{~mm})$ & TRI-5/32 & $\$ 145.08$ \\
\hline $3 / 16$ & $(4.8 \mathrm{~mm})$ & TRI-3/16 & $\$ 198.42$ \\
\hline $1 / 4$ & $(6.4 \mathrm{~mm})$ & TRI-1/4 & $\$ 420.76$ \\
\hline
\end{tabular}

Figure 7. Rare earth electrodes

\section{Data Acquisition System}

Welding data acquisition systems were investigated to track both the real time welding parameters and the welding profile signature. It is proposed to develop a database of fuel element closure welding signatures that are linked to metallurgical examinations for fusion depth and weld quality. This database provides a real time metric as a quality assurance comparison record. Because of limitations for hands-on inspection of hot fuel element welds in the hot cell, it is proposed to establish process control limits within the data acquisition system to ensure the welding stays exactly within the qualified welding parameters. By programming the various upper and lower welding power limits, the data acquisition system will alarm to warn the operator if any weld falls out of the known welding parameter or quality values. Conversely, if the weld stays within the parameters, then it is assured that the weld had the adequate volts and amperes to generate a $100 \%$ acceptable weld every time. It is proposed to use this system to augment the other quality assurance techniques to meet the intent of the ASME welding code requirements to ensure welding quality. Figure 8 shows an example of too low of welding amperes in the the welding signature.

Several welding data acquisition systems were investigated. The Arch Agent system from Impact Welding was selected because of the graphical displays it generates and the out of variance limit alarm scheme. 


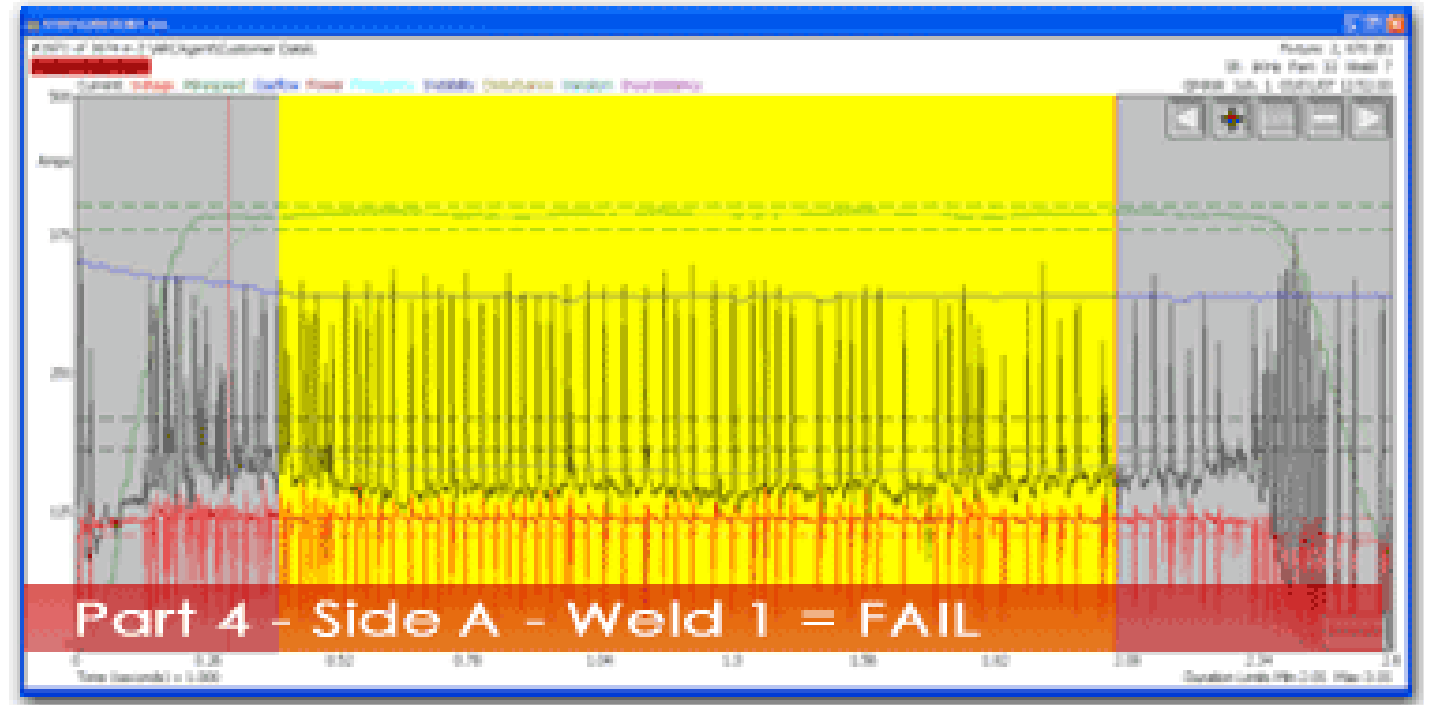

Figure 8 . Welding parameter signature

\section{Summary}

This trade-off study details salient aspects of the due diligence conducted to ascertain the best or optimum hardware or systems for supporting a well defined and mature capsule closure welding process. All of these systems directly influence the quality and precision of welded fuel elements in the nuclear environment. 